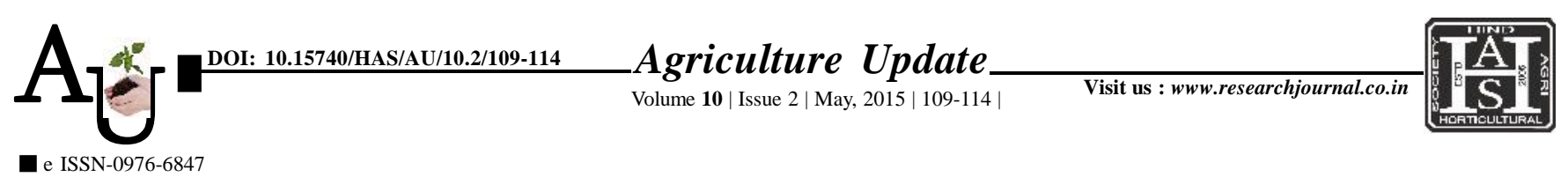

\title{
Rевевксн Автісі: Knowledge level of the onion growers about recommended cultivation practices for onion (Allium cepa) crop
}

R.N. BHISE*, N.M. KALE, Y.J. WAGHMODE, S.B. SHINDE AND J.R. KADAM

Article Chronicle:

Received :

15.09.2014;

Revised :

10.03.2015;

Accepted :

25.03.2015

KeY WoRds:

Knowledge, Adoption, Training need

Author for correspondence :

\section{R.N. BHISE}

Department of Extension Education, College of Agriculture, Dr. Balasaheb Sawant Konkan Krishi

Vidyapeeth, Dapoli, RATNAGIRI (M.S.) INDIA

Email: rushikesh.bhise@ yahoo.in

See end of the article for authors' affiliations
SUMMARY : The present research study was based on exploratory research design of social research. The field survey was carried out in Akola district of Vidarbha region of Maharashtra State during 20112012 for ascertaining the knowledge level of the onion growers about recommended cultivation practices for onion crop. The results revealed that 39.00 per cent of farmers had medium level of knowledge about recommended cultivation practices for onion crop followed by 35.00 per cent and 26.00 per cent of the farmers had high and low level of knowledge. In this context, it was implied that the information regarding recommended cultivation practices should be disseminated to the farmers by extension functionaries, KVK's, NGO's, through demonstrations, workshops, distributing printed material like leaflets; folders; etc. It will lend a hand for increasing knowledge, perception, adoption and ultimately the yield level of onion crop.

How to cite this article : Bhise, R.N., Kale, N.M., Waghmode, Y.J., Shinde, S.B. and Kadam, J.R. (2015). Knowledge level of the onion growers about recommended cultivation practices for onion (Allium cepa.) crop. Agric. Update, 10(2): 109-114. 